politics of scientific employment" which he must countersign.

Chevènement will also "be associated with" France's efforts in international scientific cooperation, in cooperation with the foreign minister M. Claude Cheysson.

The decree outlining Chevènement's powers has required negotiation at the highest possible level, and has been signed by President Mitterrand, Prime Minister Pierre Mauroy, the foreign minister and ministers of industry and education.

The national colloquium on science and technology will now take place on 13-16 January 1982, and Chevènement is laying great emphasis on its role in defining a new politics of science in France, and the major "loi-programme" for science which he is to put before parliament next year. The colloquim is to have six principal sessions: on the cultural contribution of science and scientific responsibility; on the internal division of money for science (scientific and technical options, big science and so on); the role of science in helping France to climb out of the recession and create employment; the management of scientists (contracts of employment and so on); the role of other bodies influencing science (big industry, for example); and the political and structural means adopted by Chevènement himself. Robert Walgate

\section{No rapprochement}

The usually covertly political nature of education in France came out into the open last week with the sacking of 14 of the 28 regional education officials.

These officials administer education from primary to university level within the "Académies", territories which encompass several of the French departments; ever since General de Gaulle revised their powers in 1967, they have become increasingly political figures. Madame Saunier Seïté, Giscard d'Estaing's minister of universities, was previously head of an Académie; and others became junior ministers or ministerial advisers.

In effect, this was inevitable under de Gaulle's ordinance, which loosened their hold on power and so made them more reliant on the goodwill of the government. Now fourteen unlucky incumbents have been found to be tarred too heavily with the brush of the previous administration, and must go.

This will make room for a "profound reform', the minister of education, $M$. Alain Savary, said last week in a press statement. The new administrators must not make politics, he said; they must obey the politics of the government. Their predecessors, by contrast, had been active against the new government both before and after the election. Some had stood as candidates for opposition parties. The deposed director of the Paris Académie, for example, had been Saunier Seité's chief adviser.

\section{Alternative energy conference Realism the theme}

\section{Washington}

At least five heads of state, including Canadian Prime Minister Pierre Trudeau and Mrs Indira Gandhi of India, will be among the participants at the United Nations Conference on New and Renewable Sources of Energy (UNERG) which starts in Nairobi next Monday. Their presence, together with energy and other ministers of industrialized and developing nations, is held by the conference organizers to indicate a measure of success in getting across their view of the political importance of alternatives to oil, coal, gas and nuclear energy.

But political weight alone will not guarantee a successful conference. UNERG is likely to set a very different tone from the large UN conferences of the 1970s, when global issues such as environmental pollution and the "human habitat" were confronted in a spirit of optimistic idealism.

From the beginning, UNERG has been organized with a more pragmatic outlook. It was, for example, agreed by a narrow vote of the UN General Assembly that nuclear power would not be included on the "new energy technologies" agenda, a move supported by many industrialized nations which feared the result would be too difficult to handle, but opposed by developing nations on the grounds that its exclusion - together with any explicit reference to conventional energy sources - would inevitably skew any results. But perhaps the main stimulus for pragmatism is the general feeling that grandiose schemes for new international bodies (such as the UN Environmental Programme, set up after the Stockholm conference in 1972), or even for a commitment to significant increases in development aid funds, are unlikely to gain support in an international mood of austerity.

In such a context, the tangible achievements of the Nairobi meeting will inevitably be limited. But Secretary General Enrique Iglesias, seconded to direct conference preparations from his permanent position as head of the Economic Commission for Latin America, remains confident that it can still have a real impact by bestowing legitimacy on energy sources frequently omitted from development planning.

One of the most practical parts of the conference has already been completed a series of technical reports on fourteen different types of new and renewable energy sources, from wind energy to draught animals. The quality of the reports is mixed; but some, such as that produced by an international panel on wind energy, have met with wide approval. And the preparation of national contributions for the conference is said to have catalysed thinking about alternative forms of energy production and energy planning in general - particularly in some of the developing countries - that had previously been virtually non-existent.

How these will evolve into practical initiatives remains to be seen. Several industrialized countries are said to be keen to support the setting up of research and training institutes for the various energy sources, wood-fuel being the most frequently quoted example. And the Society for International Development is promoting the idea of an international network of energy research institutes along the lines of the agricultural research network run by the World Bank.

The political debate will inevitably focus on the two factors which tend to dominate all international meetings of this nature: money (development aid contributions, primarily from the industrialized nations), and power (the organization of the UN bureaucracy).

Initially the developed and developing nations will be less far apart than at the UN Conference on Science and Technology for Development (UNCSTD) in Vienna in August 1979, where the Group of 77 arrived at the bargaining table with a proposal for a new fund to support Third World research with a budget of $\$ 2,000$ to $\$ 4,000$ million. This time the developing countries have accepted that such proposals are unrealistic. Any extra support for development of new energy technologies is therefore likely to come from changes in existing arrangements.

The conference organizers originally hoped that the meeting would coincide with the creation of a new "energy affiliate" by the World Bank, a proposal put forward by the bank's then President Robert McNamara last year as a device for raising capital for energy production schemes. So far, though, this has been vetoed by the Reagan Administration on the grounds that investment should, where possible, be left to the private sector.

With the World Bank's initiative stalled - and general agreement that the Nairobi conference should not try to set up a new energy fund - one of the most likely outcomes is an agreement that energy projects should receive a set proportion of the funds raised through a new "financing system" for science and technology, which has been in the planning stages since the Vienna meeting two years ago.

If approved in principle by the General Assembly later this year, the "financing system" would probably take over responsibility for projects at present financed through a two-year interim fund, also established at Vienna, operated by the UN Development Programme. The interim fund already supports several energy projects, such as research into the use of wind power in Mauritius and the introduction of more efficient wood-stoves into the Sahel region of Africa.

To a large extent, however, the most significant meetings will not take place in 